\title{
ZNACZENIE KLASTRÓW W ROZWOJU BRANŻ
}

\section{WSTĘP}

We współczesnej gospodarce światowej, obok postępującego procesu globalizacji, coraz większe znaczenie zaczyna mieć lokalizacja działalności gospodarczej. Przedsiębiorstwa sa zainteresowane umiejscawianiem swoich siedzib w regionach oferujących środowisko innowacyjne oraz konstruktywną presję konkurencyjną ${ }^{1}$. Regulacja czysto rynkowa, zakładająca skrajną rywalizację podmiotów, jest coraz szerzej uzupełniana przez stosunki kooperacyjne, których przykładem sa klastry. Badania przeprowadzone pod koniec XX i na początku XXI w. wykazuja, że klastry moga zapewniać szereg korzyści dla przedsiębiorstw i regionów. Sukcesy klastrów budzą entuzjazm dla współpracy w regionie i wzmacniają lokalny patriotyzm oraz wspomagaja tworzenie lokalnego łańcucha podażowego. Korzystna „atmosfera przedsiębiorczości” wokół klastrów przyciaga inwestorów, a konieczność ciagłego porównywania się z rywalami pobudza innowacyjność.

W literaturze znaleźć można wiele odniesień do korzyści płynących z uczestnictwa w strukturach klastra, zarówno w kontekście regionu, w którym jest zlokalizowany, jak i jego uczestników. Jednak Porter ${ }^{2}$ podkreślał, że jednym z atrybutów klastra jest skupienie się firm wokół jednej branży lub kilku pokrewnych. Można zatem przypuszczać, że pozytywne elementy współpracy klastrowej widoczne są także w przekroju branżowym. Celem niniejszego artykułu jest poznanie relacji pomiędzy klastrem a branża, a także odpowiedź na pytanie, czy w dotychczasowych badaniach - choć nielicznych - zauważono pozytywną relację wpływu funkcjonowania klastrów na branże. Odpowiedź na to pytanie może zapoczątkować badania nad istotnością klastra w rozwoju nie tylko regionalnym, ale również branżowym.

\section{BRANŻA JAKO MEZOEKONOMICZNA JEDNOSTKA BADAWCZA}

System gospodarczy najczęściej rozumiany jest jako zespół powiązanych ze sobą podmiotów (osób, przedsiębiorstw i instytucji) zaangażowanych $\mathrm{w}$ wymianę pieniężno-towarową na rynkư ${ }^{3}$. Jest to pojęcie obejmujące wiele

\footnotetext{
${ }^{1}$ M.E. Porter, Porter o konkurencji, Warszawa 2001.

${ }^{2}$ Idem, Strategia konkurencji. Metody analizy sektorów i konkurentów, Warszawa 1999.

${ }^{3}$ M. Gorynia, Mezoekonomia - modele samoregulacji branży, „Ekonomista” 1995, nr 5-6, s. $816-837$.
} 
zróżnicowanych jednostek, które składają się na mniejsze podsystemy. Podsystemy te także różnią się między sobą ze względu na brak homogeniczności jednostek, które je tworzą. Mają różną dynamikę i wielkość. W delimitacji podsystemów systemu gospodarczego przydatna jest ogólna teoria systemów, która zakłada, że całość składa się z mniejszych części powiązanych ze sobą relacją hierarchiczności. Zatem w kontekście ekonomii system gospodarczy można podzielić na niższe poziomy, które będą pozostawały zależne od siebie.

Przez lata nauki ekonomiczne ewoluowały i zmieniały się, a właściwie dokładały poziomy analizy. Sztandarowym podziałem jednostek analizy jest podział na poziom mikro- i makroekonomiczny odnoszący się kolejno do przedsiębiorstw i do całości gospodarki. Jednakże występują też poziomy pośrednie - tak jak chociażby mezoekonomia koncentrująca swoją uwagę na branżach i regionach, poziom mikromikro, który odnosi się do indywidualnych decyzji osób (np. agentów w firmie), a także jego odwrotny biegun, czyli poziom globalny. Mezoanaliza pozwala na połączenie perspektywy mikro- i makroekonomicznej, jednocześnie wyodrębniając części wspólne, które funkcjonują równolegle do siebie, tworząc całość gospodarki ${ }^{4}$.

Jak często zdarza się przy definiowaniu zjawisk i terminów, trudno jest w literaturze przedmiotu znaleźć jednoznaczną definicję branży. Wyodrębnienie branży związane jest z pojęciem delimitacji ${ }^{5}$, czyli wyznaczenia granic tworzących pewien wycinek systemu gospodarczego ${ }^{6}$. Odnosząc delimitację do pojęcia branży, ponownie musimy przywołać wymiar pionowy i poziomy. W wymiarze pionowym delimitacja będzie oznaczać umiejscowienie branży pomiędzy analizą mikro- i makroekonomiczną. W takim rozumieniu branża stanowi pewien podsystem gospodarki narodowej, scalający przedsiębiorstwa $\mathrm{i}$ inne podmioty występujące na rynku, np. instytucje. W wymiarze poziomym delimitacja wywołuje więcej kontrowersji. Pomijając kwestie geograficzne, które moga być rozstrzygnięte w dość logiczny i oczywisty sposób ${ }^{7}$, Marshall ${ }^{8}$ deklarował, że podstawą rozróżnienia powinna być homogeniczność technologii produkcji. Z czasem okazało się jednak, że spojrzenie wyłącznie od strony podażowej może okazać się niewystarczające. Istnieją bowiem na rynku produkty substytucyjne, które nie są wytwarzane za pomocą tej samej techno-

4 Ibidem.

${ }_{5}$ Ze względu na tematykę opracowania analiza ograniczy się jedynie do poziomu mezoekonomicznego, w którym istotnymi kryteriami delimitacji podsystemów gospodarczych będą wymiar pionowy i poziomy. Wymiar pionowy odnosi się do przyjęcia jednostki analizy oraz w kontekście wymiaru poziomego zawężenia jego obszaru geograficznego i oddziaływania na konsumenta.

${ }^{6}$ B. Jankowska, Branża jako mezosystem gospodarczy, „Ruch Prawniczy, Ekonomiczny i Socjologiczny" 64, 2002, z. 2.

7 Wyróżnia się trzy zasadnicze podziały geograficzne: kryterium administracyjne, fizyczno-geograficzne oraz ekonomiczno-przestrzenne. Kryterium administracyjne odwołuje się do jednostek terytorialnych wyodrębnionych w danym kraju. Kryterium fizyczno-geograficzne opiera się na wspólnych cechach przyrodniczych danego regionu niezależnie od przynależności administracyjnej. Kryterium ekonomiczno-przestrzenne nawiązuje do kontekstu historycznego lub rozwoju społecznego.

8 A. Marshall, Principles of Economics, Macmillan, London 1972. 
logii. Patrząc na branżę od strony popytowej, podkreśla się, że powinny je tworzyć te przedsiębiorstwa, które oferują produkt lub usługę zaspokajajacca tę samą potrzebę, niezależnie od procesu technologicznego.

Podejście substytucyjne wiąże się z koncepcją luki substytucyjnej ${ }^{9}$. Robinson $^{10}$ nawiązywała do tezy mówiącej o tym, że oferowane na rynku produkty stanowią łańcuch, który w niektórych miejscach jest poprzerywany. Przerwa w tym łańcuchu stanowi właśnie lukę substytucyjną. Branżę natomiast będą stanowić te przedsiębiorstwa, które oferują produkty w wydzielonym fragmencie łańcucha, aż do luki substytucyjnej.

Von Stackelberg ${ }^{11}$ deklarował, że branża powiązana jest z pojęciami rynku ogólnego i elementarnego. Rynek ogólny jest niedoskonały i składa się z rynków elementarnych, które z kolei cechują się pełną doskonałością. Branżę w jego rozumieniu stanowi rynek elementarny, na którym popyt jest homogeniczny.

Podobnie Porter ${ }^{12}$, definiując branżę, odnosił się do substytutów zakładajac, że sa to firmy pozostajace w konkurencji i oferujące klientowi produkty lub usługi, które są swoimi substytutami i zaspokajają ich potrzeby. Porter jednak nie wspomina o geograficznym zawężeniu tego pojęcia. W kontekście lokalizacji zarządzanie strategiczne bardzo często posługuje się pojęciem sektora, które ponownie odnosi się do produktów lub usług majacych to samo przeznaczenie, ale które sprzedawane są na tym samym rynku geograficznym.

Nie jest łatwo jednoznacznie zdefiniować pojęcie branży (tab. 1). Najbardziej ogólnym, a jednocześnie dającym się szeroko interpretować określeniem jest „grupa przedsiębiorstw wyodrębnionych według określonego kryterium, które [...] natychmiast sygnalizuje występowanie pewnych powiązań między zaliczonymi do branży przedsiębiorstwami” ${ }^{13}$. Przy takiej definicji pojawia się natomiast kolejne pytanie, czy branża powinna być utożsamiana jednie z przedsiębiorstwami, czy też zalicza się tutaj inne podmioty gospodarcze, takie jak np. instytucje branżowe. Chociaż bezpośrednio nie przyczyniają się one do produkcji lub wykonywania usług na rzecz finalnego odbiorcy pełnią względem przedsiębiorstw funkcję doradcza, lobbująca, kontrolna itp.

Delimitacja branży jest tym trudniejsza, że wraz z postępem technologicznym widoczne staje się zacieranie granic pomiędzy nimi. Tym samym trudno określić, czy dane przedsiębiorstwo należy do jednej czy drugiej branży, czy też de facto jest obecne w kilku branżach jednocześnie, gdyż jego produkty mają różne przeznaczenie. Dlatego też w różnych opracowaniach i bazach statystycznych trudno jest znaleźć jednoznaczne kryteria definiujące i wyodrębniające branże.

\footnotetext{
9 B. Jankowska, op. cit.

10 J. Robinson, The Economics of Imperfect Competition, London 1969.

11 H. von Stackelberg, Marktform und Gleichgewicht, Berlin 1934.

${ }_{12}$ M.E. Porter, Strategia..., passim.

13 B. Jankowska, op. cit.
} 
Tabela 1

„Tradycyjne” koncepcje branży

\begin{tabular}{|c|c|c|c|}
\hline Autor & $\begin{array}{l}\text { Kryterium } \\
\text { delimitacji }\end{array}$ & Definicja branży & $\begin{array}{c}\text { Zarzuty po adresem } \\
\text { teorii }\end{array}$ \\
\hline $\begin{array}{l}\text { Marshall } \\
(1972)\end{array}$ & $\begin{array}{l}\text { Homogeniczność } \\
\text { technologii pro- } \\
\text { dukcji }\end{array}$ & $\begin{array}{l}\text { Przedsiębiorstwa } \\
\text { wytwarzające produk- } \\
\text { ty o takich samych } \\
\text { charakterystykach } \\
\text { technicznych }^{a}\end{array}$ & $\begin{array}{l}\text { Dobra moga być } \\
\text { w stosunku do siebie } \\
\text { substytutami i jednako- } \\
\text { we produkty mogą być } \\
\text { wytwarzane przy uży- } \\
\text { ciu różnych technologii }\end{array}$ \\
\hline $\begin{array}{l}\text { Chamberlin } \\
\text { (1933) }\end{array}$ & $\begin{array}{l}\text { Substytucyjność } \\
\text { produktów }\end{array}$ & $\begin{array}{l}\text { Grupy konkurujących } \\
\text { ze soba firm (competing } \\
\text { group of firms) - produ- } \\
\text { centów bliskich substy- } \\
\text { tutów }^{b}\end{array}$ & $\begin{array}{l}\text { Brak obiektywnych } \\
\text { kryteriów umożliwia- } \\
\text { jących wydzielenie bli- } \\
\text { skich/dalszych substy- } \\
\text { tutów }\end{array}$ \\
\hline $\begin{array}{l}\text { Robinson } \\
\text { (1969) }\end{array}$ & $\begin{array}{l}\text { Homogeniczność } \\
\text { potrzeb }\end{array}$ & $\begin{array}{l}\text { Przedsiębiorstwa oferu- } \\
\text { jące produkty występu- } \\
\text { jące w nieprzerwanym } \\
\text { łańcuchu substytucyj- } \\
\text { nym. W jednym łańcu- } \\
\text { chu znajdują się pro- } \\
\text { dukty zaspokajające tę } \\
\text { samą potrzebę, abstra- } \\
\text { huje się od zastosowanej } \\
\text { technologii i charaktery- } \\
\text { styk produktuc }^{c}\end{array}$ & $\begin{array}{l}\text { Nierealność tezy o ist- } \\
\text { nieniu nieprzerwanego } \\
\text { łańcucha substytucyj- } \\
\text { nego i występowaniu } \\
\text { luk substytucyjnych } \\
\text { tylko w punktach } \\
\text { określających granice } \\
\text { branży }\end{array}$ \\
\hline $\begin{array}{l}\text { von Stackelberg } \\
(1934), \\
\text { Abbott (1958) }\end{array}$ & & $\begin{array}{l}\text { Branża to rynek doskona- } \\
\text { ły, charakteryzujacy się } \\
\text { homogenicznym popytem. } \\
\text { Suma takich elementar- } \\
\text { nych rynków tworzy ry- } \\
\text { nek całościowy, który jest } \\
\text { rynkiem niedoskonałym }{ }^{d}\end{array}$ & $\begin{array}{l}\text { Brak obiektywnych kry- } \\
\text { teriów umożliwiajacych } \\
\text { wydzielenie bliskich/dal- } \\
\text { szych substytutów }\end{array}$ \\
\hline $\begin{array}{l}\text { Bain (1959), } \\
\text { Porter (1999) }\end{array}$ & $\begin{array}{l}\text { Substytucyjność } \\
\text { produktów }\end{array}$ & $\begin{array}{l}\text { Określoną branżę two- } \\
\text { rzą producenci substytu- } \\
\text { tów }{ }^{e} \text { Bain stwierdził, że } \\
\text { granice rynku branżo- } \\
\text { wego wyznacza wysoki } \\
\text { współczynnik elastycz- } \\
\text { ności krzyżowej }\end{array}$ & $\begin{array}{l}\text { Brak obiektywnych kry- } \\
\text { teriów umożliwiajacych } \\
\text { wydzielenie bliskich/ } \\
\text { dalszych substytutów, } \\
\text { zastrzeżenia pod adresem } \\
\text { pojęcia elastyczności } \\
\text { krzyżowej popytug }\end{array}$ \\
\hline
\end{tabular}

${ }^{a}$ A. Marshall, op. cit.

${ }^{b}$ D.A. Hay, D.J. Morris, Industrial Economics. Theory and Evidence, Oxford 1979, s. 10.

${ }^{c}$ J. Robinson, op. cit., s. 17.

${ }^{d}$ H. von Stackelberg, op. cit., s. 29; L. Abbott, Qualität und Wettbewerb, München 1958, s. 96.

${ }^{e}$ M.E. Porter, Strategia..., passim.

${ }^{f}$ J.S. Bain, Industrial Organization, New York 1959, s. 6-7.

${ }^{g}$ D. Needham, Economic Analysis and Industrial Structure, Holt 1978.

Źródło: B. Jankowska, A. Kania, Branże jako uczestnicy i receptory kryzysu, w: M. Dzikowska, M. Gorynia, B. Jankowska (red.), Międzynarodowa konkurencyjność polskich przedsiębiorstw w okresie globalnego kryzysu gospodarczego i po jego wystapieniu, Warszawa 2016. 
W Unii Europejskiej wprowadzono wspólną klasyfikację działalności gospodarczej opartą w większości na definicji Marshalla ${ }^{14}$. Na jej podstawie stworzono agregaty o czterech poziomach szczegółowości: sekcje, dywizje, grupy i klasy. Sekcje odnoszą się do bardzo ogólnej charakterystyki, dzieląc działalność gospodarczą na produkcję, rolnictwo, sprzedaż hurtową i detaliczna itd. Dywizje oraz grupy (przy czym grupy są bardziej szczegółowe niż dywizje) wydzielane są na podstawie trzech zasadniczych reguł:

- rodzaju dostarczanych produktów i usług;

- przeznaczenia dostarczanych produktów i usług;

- potrzebnych w procesie technologicznym nakładów.

Ostatnia z kategorii, klasy, oparta jest w pierwszej kolejności na podobieństwie w procesie technologicznym. Grupy, które już obejmują kryterium podobieństwa i przeznaczenia produktów, sa jeszcze dodatkowo dzielone ze względu na podobieństwo przebiegu samego procesu technologicznego. W tym kontekście klasy odpowiadają Marshallowskiemu rozumieniu branży. Klasyfikacja ta jest obowiązkowa dla wszystkich członków Unii Europejskiej, dopuszcza się jednak wprowadzenie krajowych odpowiedników klasyfikacji NACE. W Polsce obowiązuje oparta na niej klasyfikacja PKD 2007.

\section{KLASTRY JAKO ELEMENT FUNKCJONOWANIA BRANŻY}

Koncepcja klastrów łączy w sobie różne ujęcia i nurty badawcze $\mathrm{z}$ wielu dziedzin nauki: ekonomii, nauk organizacji i zarządzania oraz socjologii. Dodatkowo różnorodność w zakresie definicji klastrów jest wynikiem istnienia wielu szkół w samej ekonomii i ich odmiennych perspektyw postrzegania świata. Skutkiem tego zjawiska jest duża elastyczność w pojmowaniu koncepcji klastrów.

W 1890 r. Marshall ${ }^{15}$ opisał dystrykty przemysłowe, w ramach których przedsiębiorstwa znajdujące się w geograficznej bliskości wchodziły ze soba w relacje zarówno kooperacyjne, jak i konfrontacyjne. Jego zdaniem skupiska firm w regionie Yorkshire, wyspecjalizowane w produkcji wełny, wyróżniały się „stałą wymianą idei między twórcami a użytkownikami maszyn”16. Marshall zaobserwował również, że małe przedsiębiorstwa zlokalizowane w dystryktach osiagały podobne efekty jak duże firmy. Korzyści te można było przypisać nie ekonomii skali, ale regionalnym efektom zewnętrznym, których występowanie Marshall opisywał przez:

- ułatwioną dyfuzję wiedzy,

- przewagę kreowaną przez lokalny rynek pracy koncentrujacy osoby o odpowiednich umiejętnościach,

14 A. Marshall, op. cit.

15 Ibidem.

16 E. Skawińska, R. Zalewski, Klastry biznesowe $w$ rozwoju konkurencyjności i innowacyjności regionów: świat-Europa - Polska, Warszawa 2009, s. 21. 
- sieci powiązań pomiędzy dostawcą i odbiorcą w ramach dużych rynków regionalnych.

Co ciekawe, Marshall ${ }^{17}$ dostrzegł zjawisko koncentrowania się branż w określonych sektorach, ponieważ obserwowana wysoka koncentracja sektorów nie prowadziła do spadku atrakcyjności rynku. Wprost przeciwnie, w badanych skupiskach koncentracja ta stanowiła czynnik zachęcający kolejnych inwestorów do otwierania fabryk. Zdaniem Marshalla dystrykty przemysłowe, w wyniku powstawania pozytywnych efektów zewnętrznych, odgrywały znacząca rolę w budowaniu potęgi gospodarczej regionów. W latach trzydziestych XX w. Ohlin jako przyczynę tworzenia się klastrów wskazywał korzyści aglomeracji wynikające z:

- wewnętrznych korzyści skali związanych z techniką produkcji lub funkcja produkcji pojedynczego przedsiębiorstwa,

- korzyści lokalizacji wynikających z oddziaływania branży na pojedyncze podmioty,

- korzyści urbanizacji opartych na rozmiarze gospodarki w danym regionie, mających charakter zewnętrzny w stosunku do branży i firm,

- powiązań między branżami związanych z transakcjami wymiany ${ }^{18}$.

W połowie XX w. Perroux stworzył koncepcję tzw. sektorowych i terytorialnych biegunów wzrostu (ang. growth poles), czyli branż lub przedsiębiorstw dominujących, wspomaganych przez inne branże gospodarki skupione wokół nich i powodujące efekty aglomeracji. Tym samym rozwój gospodarczy w regionie w ramach tej koncepcji ma charakter spolaryzowany - bieguny wzrostu rozwijają się szybciej od pozostałych obszarów. Zgodnie z założeniami Perroux przedsiębiorstwa dominujące będące biegunami wzrostu to na ogół firmy innowacyjne, które reprezentują dynamicznie rozwijającą się branżę gospodarki i prezentują wyższy poziom niż inne otaczające je jednostki. Głównym założeniem teorii francuskiego badacza był pozytywny wpływ biegunów wzrostu dla rozwoju miejscowej gospodarki i przenoszenie się z nich impulsów rozwojowych na inne jednostki ${ }^{19}$.

Przełomowym momentem w badaniach nad zjawiskiem klastrów było opublikowanie w 1990 r. The Competitive Advantage of Nations Portera, zgodnie z którym klastry charakteryzowane sa jako przejaw wzajemnego oddziaływania poszczególnych składników diamentu Portera ${ }^{20}$. Mogą być także rozumiane jako „geograficzne skupiska wzajemnie powiązanych firm, wyspecjalizowanych dostawców, jednostek świadczących usługi, firm działających w pokrewnych sektorach i związanych z nimi instytucji (na przykład uniwersytetów, jednostek normalizacyjnych i stowarzyszeń branżowych), konkurujących, ale także współpracujących”" ${ }^{1}$. Dzięki bliskość innowacyjnych branż

17 A. Marshall, op. cit.

18 M. Gorynia, B. Jankowska, Klastry a międzynarodowa konkurencyjność i internacjonalizacja przedsiębiorstwa, Warszawa 2008, s. 31; E. Skawińska, R. Zalewski, op. cit., s. 23-24.

${ }^{19}$ A.M. Kowalski, Kooperacja w ramach klastrów jako czynnik zwiększania innowacyjności i konkurencyjności regionów, „Gospodarka Narodowa” 2010, nr 5-6(225-226), s. 5.

${ }^{20}$ M.E. Porter, The Competitive Advantage of Nations, New York 1990, s. 71-73.

21 Idem, Porter..., passim. 
pokrewnych, wspierajacych oraz powiazanych z nimi instytucji, w ramach klastra, podobieństwa w zakresie np. technologii, umiejętności, klientów, infrastruktury, dostawców, pełnionych funkcji pozytywnie wpływają na technologiczne efekty przenikania.

Obecnie w literaturze przedmiotu toczą się spory dotyczące bardziej precyzyjnego rozumienia koncepcji klastrów. Krytycy klastrów podkreślają nieprecyzyjność definicyjną idei, która nie musi wprawdzie powodować trudności na poziomie koncepcyjnym, ale generuje już problemy na poziomie empirycznym $^{22}$. W większości definicji brakuje konkretnego ograniczenia pewnych pojęć i wyraźnego zrozumienia poszczególnych idei, co może prowadzić do błędów w prowadzonych badaniach empirycznych. $Z$ tego względu na potrzeby niniejszego artykułu przyjęte zostało następujące rozumienie atrybutów klastrów Ketelsa ${ }^{23}$ :

- bliskość geograficzna - kierując się licznymi badaniami empirycznymi w literaturze, które sprowadzają to pojęcie do rozważań na poziomie NUTS I, II lub III, atrybut ten jest rozumiany jako skupienie się członków klastra w ramach podstawowej jednostki terytorialnej. Przy założeniu, że klastry nie działaja na poziomie krajowym, ale lokalnym i musi istnieć niewielka odległość pomiędzy podmiotami, aby mogło dojść do silnych powiązań między nimi, za Durantonem i Overmanem ${ }^{24}$ zostaje przyjęta odległość od 0 do $50 \mathrm{~km}$ dla firm z tej samej branży oraz do $150 \mathrm{~km}$ dla dostawców i organizacji wspierajacych.

- powiazane firmy - rozumiane jako przedsiębiorstwa prowadzace podobną działalność i wyspecjalizowane w podobnych dziedzinach. Firmy te łączy również podobny poziom rozwoju technologicznego i rynkowego ${ }^{25}$;

- masa krytyczna - Brenner ${ }^{26}$ definiuje mase krytyczną jako: „stan rozwoju klastra, poprzedzony fazą embrionalna, w którym klaster działa stabilnie". Zgodnie z badaniami przeprowadzonymi przez niego w Niemczech masa krytyczna waha się w granicach od 3 do 87 jednostek, przy czym najczęściej występujące wartości to 3-2027;

- aktywne interakcje pomiędzy podmiotami - rozumiane jako więzi pomiędzy uczestnikami klastra, które generują efekty zewnętrzne i dzięki którym firmy zyskują dodatkowe korzyści (np. większa mobilność siły roboczej, ułatwiony transfer technologii i wiedzy, powstawanie firm odpryskowych, pozioma i pionowa współpraca pomiędzy firmami itp. $)^{28}$.

${ }^{22}$ D. Fornahl, S. Henn, M.P. Menzel, Emerging Clusters. Theoretical, Empirical and Political Perspectives on the Initial Stage of Cluster Evolution, Cheltenham 2010, s. 10.

${ }^{23}$ Ch. Ketels, European Clusters, Boston 2004.

${ }^{24}$ G. Duranton, H.G. Overman, Testing for localization using micro-geographic data, „Review of Economic Studies" 72(4), 2005.

${ }^{25}$ D. Fornahl, S. Henn, M.P. Menzel, op. cit., s. 8.

${ }^{26}$ T. Brenner, Industrial Districts: A Typology from an Evolutionary Perspective, Max-Planck-Institute for Research into Economic Systems Evolutionary Economics Unit, Jena 2000.

${ }_{27}$ T. Brenner, Identification of local industrial clusters in Germany, „Regional Studies” 40(9), 2006, s. 996-998.

${ }^{28}$ D. Fornahl, S. Henn, M.P. Menzel, op. cit., s. 8. 


\section{WSPÓŁZALEŻNOŚĆ KLASTRÓW I BRANŻ W KREOWANIU WARTOŚCI DODANEJ}

Opierając się na powyżej przedstawionej charakterystyce, można przyjąć, że klastry funkcjonujące w danej branży, a czasem na pograniczu kilku branż, pozostaja we wzajemnych relacjach. Klastry rozwijają się w ramach specyficznych uwarunkowań charakterystycznych dla danych lokalizacji i mają tym samym dość niepowtarzalny charakter. Niemniej interakcje między klastrami a branżami mają charakter dwukierunkowy. Typ, dynamika czy faza cyklu życia branży mogą determinować działalność klastra, jednakże równocześnie klaster wpływa na strukturę i strategię przedsiębiorstw w branży. Korzyści branżowe, jakie moga pojawić się w ramach tych współzależności, mogą przybierać dwojaki charakter - korzyści dla indywidualnych uczestników branży, jak również branży jako kolektywu ${ }^{29}$.

Analizy teoretyczne i liczne studia przypadków wskazują że klastry moga zapewniać szereg korzyści dla przedsiębiorstw, regionów i branż, w ramach których funkcjonują. Ponieważ zagadnienie korzyści płynących z funkcjonowania klastra dla indywidualnych uczestników rynku zostało już dogłębnie przeanalizowane, niniejsze studium skupiać się będzie na drugiej perspektywie, czyli korzyści płynących dla branży rozumianej jako całość. Pozytywne efekty związane z istnieniem klastra nie dotycza jedynie jego uczestników, ale w wyniku tzw. efektów rozprzestrzeniania (ang. spillover effects) przenikaja również do jego otoczenia. W perspektywie całej branży funkcjonowanie klastrów może prowadzić do m.in. do:

- spadku ogólnego poziomu kosztów transakcyjnych ${ }^{30}$,

- powstania korzyści skali ${ }^{31}$,

- efektu przenikania wiedzy oraz usprawnienia jakości obiegu wiedzy i dostępu do informacji ${ }^{32}$,

- powstawania firm odpryskowych ${ }^{33}$,

${ }^{29}$ Dyskusyjne pozostaje, czy branżę można faktycznie - zgodnie z ideą holizmu - utożsamiać z kolektywem, czyli bytem, który nie stanowi jedynie sumy przedsiębiorstw w niej działających. Autorki opowiadają się za teza, że branża posiada cechy niewynikające jedynie z działalności firm, czyli np. stopień koncentracji czy strukturę, zatem mogą one być analizowane z punktu widzenia kolektywu.

${ }^{30}$ C. Steinle, H. Schiele, When do industries cluster? A proposal on how to assess an industry's propensity to concentrate at a single region or nation, „Research Policy” 31(6), 2002.

${ }^{31}$ G. Halder, Local upgrading strategies in response to global challenges: the surgical instrument cluster of Tuttlingen, Germany, w: H. Schmitz, Local Enterprises in the Global Economy: Issues of Governance and Upgrading, Northampton 2004; H. Rocha, R. Sternberg, Entrepreneurship: The Role of Clusters Theoretical Perspectives and Empirical Evidence from Germany, „Small Business Economics" 24(3), 2005.

${ }^{32}$ B. Alecke, C. Alsleben, F. Scharr, G. Untiedt, Are there really high-tech clusters? The geographic concentration of German manufacturing industries and its determinants, „Annals of Regional Science” 40(1), 2006; Ö. Sölvell, G. Lindqvist, Ch. Ketels, Zielona Ksiega Inicjatyw Klastrowych, Inicjatywy Klastrowe $w$ gospodarkach rozwijajacych się $i w$ fazie transformacji, Center for Strategy and Competitiveness, Sztokholm 2006.

${ }^{33}$ K. Wennberg, G. Lindqvist, How do entrepreneurs in clusters contribute to economic growth?, SSE/EFI Working Paper Series in Business Administration, no. 2008, Stockholm School of Economics, Stockholm 2008. 
- wzrostu atrakcyjności lokalizacyjnej branży dla zagranicznych inwestycji bezpośrednich ${ }^{34}$,

- rozbudowy kapitału społecznego oraz nasilenia się więzi społecznych, a więc wzrostu wzajemnego zaufania partnerów, co wspomagają nieformalne kontakty uczestników klastra ${ }^{35}$,

- pojawianiu się nowych miejsc pracy i wzmocnienia potencjału kadrowego ${ }^{36}$,

- tworzenia się środowiska sprzyjającego innowacjom ${ }^{37}$,

- poprawy wizerunku branży oraz rozwój funkcji targowo-wystawienniczych ${ }^{38}$,

- kreacji nowych branż (tzw. emerging industries).

Korzyści z funkcjonowania klastra wynikaja głównie z geograficznej bliskości licznej grupy niezależnych podmiotów, nagromadzenia określonej wiedzy, wysoko wykwalifikowanych pracowników, specjalizacji, łatwości znalezienia podwykonawców i usługodawców oraz realizacji wspólnych działań w pewnych obszarach. Skala pozytywnych efektów dla regionu i branży zależna jest od typu branży, w której działa klaster, etapu jego rozwoju, poziomu konkurencji w regionie, regionalnych warunków brzegowych i szeregu innych czynników ${ }^{39}$.

W literaturze przedmiotu podejmuje się próby tworzenia typologii klastrów według różnych kryteriów: stadium rozwoju, pozycji konkurencyjnej, znaczenia technologii, zasięgu terytorialnego klastra czy zdolności do kreowania miejsc pracy. W każdym typie doszukać się można specyficznych uwarunkowań i priorytetów, które mogą wykazywać bezpośrednie przełożenie na rozwój niektórych typów branż.

Strategia lizbońska, a także strategia Europe 2020 wskazuja, że podstawowym czynnikiem rozwoju gospodarczego krajów będą sektory wysokich technologii ${ }^{40}$. Przyjmuje się, że branże oparte na wysokich technologiach to te, których nakłady na badania i rozwój przekraczają 7\%. Charakteryzują się wysoką kapitałochłonnościa, wysokim ryzykiem podejmowanych inwestycji oraz krótkimi cyklami życia produktów/usług. Intensywność działań branż high-tech jest różna w różnych krajach. W Polsce przedsiębiorstwa high-tech, według podziału dziedzinowego, stanowią jedynie ok. 9\% ${ }^{41}$ wszystkich przedsiębiorstw i łącznie generuja jedynie ok. 6\% wpływów z eksportu Polski. Jest to niewiele w porównaniu z innymi gospodarkami, gdzie działalność sektorów high-tech jest o wiele bardziej widoczna. Najwyższy wskaźnik eksportu w tym zakresie wykazują Chi-

\footnotetext{
${ }^{34}$ A.M. Kowalski, op. cit.

35 S.A. Rosenfeld, Expanding opportunities: cluster strategies that reach more people and more places, „European Planning Studies” 11(4), 2003.

36 A. Isaksen, Regional clusters and competitiveness: the Norwegian case, „European Planning Studies" 5(1), 1997.

${ }_{37}$ T.B. Folta, A.C. Cooper, Y. Baik, Geographic cluster size and firm performance, „Journal of Business Venturing” 21(2), 2006; C. Steinle, H. Schiele, op. cit.

38 A.M. Kowalski, op. cit.

${ }^{39}$ R. Martin, P. Sunley, Deconstructing clusters: chaotic concept or policy panacea?, „Journal of Economic Geography” 3(1), 2003.

${ }^{40}$ A. Zakrzewska-Bielawska, Rozwój przedsiębiorstw high-tech, w: eadem (red.), Koopetycja $w$ rozwoju przedsiębiorstw high-tech, Warszawa 2014.

${ }^{41}$ Dane za 2014 r. W latach 2010-2013 wartość ta jednak była podobna i nie przekroczyła 10\%.
} 
ny, po nich Unia Europejska (z Niemcami, Holandia, Francją i Wielką Brytania na czele) oraz Stany Zjednoczone. Jak wynika z tabeli 2, wiele z istniejaccych typów klastrów pozytywnie oddziałuje na branże wysokich technologii. Oznacza to, że istnienie, a raczej działalność klastrów intensyfikuje prace badawczo-rozwojowe, innowacyjne i dynamikę wzrostu w tych branżach. Korzyści branżowe moga mieć tutaj dwojaki charakter - korzyści osiaganych z perspektywy firm-uczestników branży (np. wzrost zyskowności, ograniczenie dostępu do rynku) oraz szerzej - jej uczestników oraz ich klientów (np. wzrost zaawansowania technologicznego produktów, powstawanie innowacji).

Tabela 2

Korzyści branżowe a typ klastra

\begin{tabular}{|c|c|c|c|c|}
\hline $\begin{array}{c}\text { Typ } \\
\text { klastra }\end{array}$ & $\begin{array}{c}\text { Klastry } \\
\text { oparte } \\
\text { na wiedzy }\end{array}$ & $\begin{array}{c}\text { Klastry } \\
\text { oparte na } \\
\text { korzyści skali }\end{array}$ & $\begin{array}{c}\text { Klastry } \\
\text { uzależnione od } \\
\text { dostawcy }\end{array}$ & $\begin{array}{c}\text { Klastry } \\
\text { wyspecjalizo- } \\
\text { wanych } \\
\text { dostawców }\end{array}$ \\
\hline $\begin{array}{l}\text { Charakte- } \\
\text { rystyka }\end{array}$ & $\begin{array}{l}\text { skupiają firmy, } \\
\text { dla których klu- } \\
\text { czowy jest bez- } \\
\text { pośredni dostęp } \\
\text { do badań pod- } \\
\text { stawowych oraz } \\
\text { publicznych insty- } \\
\text { tucji badawczych } \\
\text { i uczelni wyższych }\end{array}$ & $\begin{array}{l}\text { skupiają przed- } \\
\text { siębiorstwa pro- } \\
\text { wadzące badania } \\
\text { dla własnych } \\
\text { potrzeb, powiąza- } \\
\text { ne z instytucjami } \\
\text { technicznymi } \\
\text { i szkołami wyż- } \\
\text { szymi, bazują na } \\
\text { zewnętrznych } \\
\text { dostawcach tech- } \\
\text { nologii }\end{array}$ & $\begin{array}{l}\text { skupiają firmy } \\
\text { importujące tech- } \\
\text { nologie w formie } \\
\text { dóbr kapitało- } \\
\text { wych i półpro- } \\
\text { duktów, których } \\
\text { działalność inno- } \\
\text { wacyjna deter- } \\
\text { minowana jest } \\
\text { przez zdolności } \\
\text { do współdziałania } \\
\text { z dostawcami }\end{array}$ & $\begin{array}{l}\text { skupiają przedsię- } \\
\text { biorstwa o dużej } \\
\text { intensywności } \\
\text { prac badawczo- } \\
\text {-rozwojowych, } \\
\text { kłada nacisk na } \\
\text { innowacje pro- } \\
\text { duktowe }\end{array}$ \\
\hline $\begin{array}{l}\text { Typ branż } \\
\text { najbardziej } \\
\text { korzystają- } \\
\text { cych }^{a}\end{array}$ & $\begin{array}{l}\text { wysokie techno- } \\
\text { logie }\end{array}$ & $\begin{array}{l}\text { średnie i średnio } \\
\text { wysokie techno- } \\
\text { logie }\end{array}$ & niskie technologie & $\begin{array}{l}\text { wysokie techno- } \\
\text { logie }\end{array}$ \\
\hline $\begin{array}{l}\text { Główne } \\
\text { korzyści } \\
\text { dla branży }\end{array}$ & $\begin{array}{l}\text { - wzrost potencja- } \\
\text { łu rozwojowego } \\
\text { - wzrost zyskow- } \\
\text { ności branży } \\
\text { - obniżenie kosz- } \\
\text { tów produkcyj- } \\
\text { nych i transak- } \\
\text { cyjnych } \\
\text { - kreacja branż } \\
\text { odpryskowych } \\
\text { (spin-off) }\end{array}$ & $\begin{aligned} \text { - obniżenie kosz- } \\
\text { tów produkcyj- } \\
\text { nych i transak- } \\
\text { cyjnych } \\
\text { - korzyści skali } \\
\text { - wzrost powią- } \\
\text { zań w ramach } \\
\text { potrójnej helisy } \\
\text { (triple helix) }\end{aligned}$ & $\begin{array}{l}\text { - rozwój powią- } \\
\text { zań sieciowych } \\
\text { w branży } \\
\text { - obniżenie kosz- } \\
\text { tów transakcyj- } \\
\text { nych } \\
\text { - obniżenie korzy- } \\
\text { ści skali }\end{array}$ & $\begin{array}{l}\text { - kreacja branży } \\
\text { odpryskowych } \\
\text { (spin-off) } \\
\text { - wzrost poten- } \\
\text { cjału innowacyj- } \\
\text { nego } \\
\text { - wzrost barier } \\
\text { wejścia do bran- } \\
\text { ży }\end{array}$ \\
\hline Przykład & $\begin{array}{l}\text { farmaceutyki, } \\
\text { przemysł lotniczy, } \\
\text { chemia, elektro- } \\
\text { nika }\end{array}$ & $\begin{array}{l}\text { przemysł samo- } \\
\text { chodowy, maszy- } \\
\text { nowy, spożywczy }\end{array}$ & $\begin{array}{l}\text { rolnictwo; leśnic- } \\
\text { two; tradycyjny } \\
\text { przemysł prze- } \\
\text { twórczy: włókien- } \\
\text { niczy, meblarski, } \\
\text { metalowy }\end{array}$ & $\begin{array}{l}\text { sprzęt i oprogra- } \\
\text { mowanie kompu- } \\
\text { terowe }\end{array}$ \\
\hline
\end{tabular}

${ }^{a}$ klasyfikacja zgodnie z Eurostatem

${ }^{b}$ korzyść jedynie dla firm już zlokalizowanych w branży

Źródło: opracowanie własne. 
W kontekście przełożenia działalności klastrów na branże warto także przyjrzeć się perspektywie cyklu życia klastra, przez który przechodzi większość z nich. Model dynamiki klastra wyróżnia pięć faz w cyklu życia klastra:

- etap 0 - wyłonienie się branży stanowiącej rdzeń klastra,

- etap 1 - firmy dzięki silnej presji ze strony rywali stają się bardziej konkurencyjne i innowacyjne. W czasie gdy przedsiębiorstwa walczą o pozyskanie zamówień i powiększenie udziałów w rynku, presja pobudza innowacje produktowe i procesowe;

- etap 2 - firmy wewnątrz grupy zaczynają współpracować w odpowiedzi na nasilona zewnętrzną konkurencję. Istnieje niebezpieczeństwo przekształcenia się grupy w mało innowacyjną i zamkniętą na nowe pomysły;

- etap 3 - wzrost zaufania między partnerami prowadzi do dzielenia się wiedzą i zasobami. Ten poziom współpracy jest bardziej ryzykowny, ale może przynieść wzrost konkurencyjności, np. wspólne rozwijanie nowych produktów;

- etap 4 - sukces klastra przyciaga nowe firmy, nowe źródła kapitału i nowe talenty. Jest to zjawisko korzystne, choć niekiedy może stanowić wyzwanie dla klastra.

- etap 5 - współpraca koncentruje się na kształtowaniu przyszłości klastra ${ }^{42}$.

Niekiedy w literaturze przedmiotu do powyższej charakterystyki dodawany jest także ostatni etap - faza renesansu, rozumiana jako okres, kiedy klaster po osiagnięciu dojrzałości zamiast natychmiast wejść w fazę schyłkową przechodzi do fazy adaptacyjnej. Może to być spowodowane przez wprowadzenie innowacji technologicznej, wejście na nowe rynki zbytu, nawiązanie współpracy z nowymi przedsiębiorstwami czy też zmianę strategii działania ${ }^{43}$. Warto zauważyć, że w opisanym cyklu życia im dojrzalszy jest klaster/inicjatywa klastrowa, tym większe istnieją szanse na osiagnięcie pozytywnych efektów zewnętrznych dla branży. Tym bardziej istotne wydaje się przetrwanie inicjatywy klastrowej w momencie zakończenia dopływu zewnętrznych źródeł finansowania współpracy. Korzyści dla branży płynące z funkcjonowania klastrów w różnych fazach życia przedstawia tabela 3.

Należy również podkreślić, że mimo możliwości wystapienia licznych korzyści, klastry nie zawsze muszą stanowić doskonałe panaceum na konkurencyjność i hasło „klaster jak plaster” nie zawsze może mieć w danej sytuacji uzasadnienie. Istnieje cały szereg barier, które mogą blokować pojawianie się korzyści z działalności klastra, jak:

- obecność w branży dominującej firmy, która przejmie kontrolę nad pozostałymi uczestnikami klastra;

- niedostateczne doświadczenie organizacji pośredniczących w tworzeniu się więzi między podmiotami klastra;

- wysokie koszty członkostwa w organizacjach samorządu gospodarczego ${ }^{44}$.

${ }^{42}$ M. Smith, Exploring Cluster Dynamics Using Systems Thinking Methodology - An International Study, Scottish Enterprise, Glasgow 2008, s. 5-7.

${ }^{43}$ C. Boja, Clusters models, factors and characteristics, „International Journal of Economic Practices and Theories" 1(1), 2011, s. 42.

44 S.A. Rosenfeld, op. cit. 
Tabela 3

Cykl życia klastra a efekty branżowe

\begin{tabular}{|c|c|c|}
\hline Faza & Korzyści & Przykłady \\
\hline Etap I & - wzrost znaczenia branży w gospodarce & \multirow{5}{*}{$\begin{array}{l}\text { - szereg branż w północ- } \\
\text { no-zachodnim regionie } \\
\text { Anglii, w tym motory- } \\
\text { zacyjna, lotnicza, tury- } \\
\text { styczna, finansowa }\end{array}$} \\
\hline Etap II & $\begin{array}{l}\text { - wzrost innowacyjności branży } \\
\text { - wzrost efektu przenikania wiedzy }\end{array}$ & \\
\hline Etap III & $\begin{array}{l}\text { - intensyfikacja koopetycji } \\
\text { - obniżenie kosztów transakcyjnych } \\
\text { - efekty skali } \\
\text { - wzrost atrakcyjności branży w danej lokalizacji }\end{array}$ & \\
\hline Etap IV & $\begin{array}{l}\text { - wzrost poziomu umiędzynarodowienia branż } \\
\text { - powstawanie regulacji wspierających istnienie branż }\end{array}$ & \\
\hline Etap V & $\begin{array}{l}\text { - powstawanie nowych branż, w tym branż, w których } \\
\text { zacierają się granice między usługami a produkcją }\end{array}$ & \\
\hline
\end{tabular}

Źródło: opracowanie własne.

Brenner i Gildener ${ }^{45}$ zauważyli z kolei, że wpływ klastrów na rozwój regionu i branży zmienia się wraz z biegiem czasu, co jest szczególnie widoczne w klastrach, które działają dłużej niż 50 lat. Badacze stwierdzili, że wprawdzie „stare” klastry odgrywają nadal pozytywną rolę dla poziomu zatrudnienia, dochodów ludności i liczby start-upów, ale niekoniecznie motywuja podmioty w branży do wprowadzania nowych technologii. Rezultaty ich badań zdają się potwierdzać założenie, że klastry wraz z upływem czasu muszą przystosowywać się do nowego kontekstu i nowych wyzwań albo przejdą z fazy schyłkowej do upadku.

\section{PODSUMOWANIE}

W szybko zmieniającym się otoczeniu gospodarczym klastry mogą odgrywać coraz bardziej istotna rolę w budowaniu konkurencyjności przedsiębiorstw, regionów, branż i całych gospodarek. Zjawisko to napotyka jednak szereg przeszkód i jego pełna efektywność uzależniona jest od spełnienia szeregu warunków. W ciagu ostatnich kilkudziesięciu lat władze zarówno na poziomie centralnym, jak i regionalnym w różnych krajach na świecie zaczęły zdawać sobie sprawę, że receptą na sukces sa skoordynowane, celowe działania w ramach potrójnej helisy, czyli sieci powiązań między trzema kluczowymi aktorami systemu gospodarczego: przedsiębiorstwami, światem nauki (uniwersytetami i instytucjami $\mathrm{B}+\mathrm{R}$ ) oraz władzami szczebla regionalnego. Polityka klastrowa powstaje na pograniczu różnych polityk i jest ich hybryda,

${ }_{45}$ T. Brenner, A. Gildner, The long-term implications of local industrial clusters, „European Planning Studies” 14(9), 2006. 
ukierunkowaną zarówno na poziom mikro, jak i mezo. Można też zauważyć, że ma charakter wielowątkowy: z jednej strony jej celem jest rozwój regionu, a z drugiej - rozwój danych branż gospodarki. Stąd konstrukcja adekwatnych narzędzi polityki klastrowej wymaga lepszego poznania zależności, jakie występują pomiędzy funkcjonowaniem klastrów a rozwojem branż. W świetle przytoczonej literatury niewątpliwie można uznać, że ten wpływ istnieje, jednakże niewiele można powiedzieć o warunkach brzegowych, jakie muszą zostać spełnione, aby skutki te były realnie odczuwalne. Sugeruje to zatem, że obok tak popularnego kierunku badań empirycznych nad wpływem klastrów na rozwój regionalny, mógłby (a nawet powinien) wykształcić się kierunek skupiony na perspektywie branżowej.

dr Aleksandra Kania

Uniwersytet Ekonomiczny w Poznaniu

aleksandra.kania@ue.poznan.pl

https://orcid.org/0000-0002-7721-5750

dr Katarzyna Mroczek-Dabrowska

Uniwersytet Ekonomiczny w Poznaniu

katarzyna.mroczek-dabrowska@ue.poznan.pl

https://orcid.org/0000-0002-9015-899X

\section{THE IMPORTANCE OF CLUSTERS IN THE DEVELOPMENT OF INDUSTRIES}

\section{Summary}

Competition is an indispensable element of business activity; it is also the engine of technological progress and development of industries, regions and countries. However, the ties that are established between entities in the economic reality do not only take the form of competition. This approach has become particularly important in the last fifty years, in the conditions of progressive globalisation, the development of information technologies and the growing role of innovation as a key success factor in business. Paradoxically, the increase in the intensity of competition has led to a greater interest in relationships in which cooperation is intertwined with competition. The recent popularity of the cluster concept indicates that business entities are interested in the phenomenon of a simultaneous cooperation and competition as an effective business strategy. The aim of this article is to answer the question whether it is possible to assume that clusters play a positive role in the development of industries. The research presented in the article is qualitative and based on literature studies. The first part of the article presents the industry as a meso-economic research unit. The authors consider a cluster as an element of industry's operation. The most important benefits of cluster operations are indicated. In the light of the literature studies presented, it can be concluded that a positive impact of clusters on the industry does exist, but the definition of boundary conditions, which must be met in order for these effects to be realistically felt, requires further research. 
